\title{
Foreign Communicative Competence Development of Higher School Students in the Process of Foreign Language Teaching
}

\author{
Olena Znanetska \\ Associate Professor, Candidate of Psychological Sciences, \\ Department of Foreign Languages for Engineering and Natural Specialities, \\ Oles Honchar Dnipropetrovsk National University \\ E-mail address: znanetska@i.ua
}

\begin{abstract}
Keywords: Foreign Communicative Competence, the Notion of Competence, the Structure of Competence, Foreign Language Teaching, Approaches in Foreign Language Teaching
\end{abstract}

\begin{abstract}
In the current article the problem of foreign communicative competence of higher school students has been considered. The notion, the main point and the components of higher school students' foreign competence have been analyzed. The scientific works under the problem have been investigated.
\end{abstract}

\section{Introduction}

Nowadays in Ukraine, in the conditions of greater expansion of international relations and collaboration, the knowledge of a foreign language by modern specialists has been acquiring a special value. Professional international communication, the opportunities of training courses abroad stipulate the necessity of complete use of foreign language possibilities for professional preparation of future specialists in different fields of functioning. A specialist in any sphere must know a foreign language at such a level that would allow him to effectively carry out communication with foreign partners both in verbal and writing forms. All the above-mentioned determines the urgency of foreign competence forming problem for higher school students.

The aim of the article is to consider the concept, essence and main components of foreign communicative competence of higher educational establishment students, as well as to define basic method problems that arise during foreign language teaching in higher school, and to set factors which could simulate their emergence and to offer the ways of their overcoming.

The role of active methods in the practice of foreign language teaching has been important enough. The authors of the works devoted to the problems of language grounding, mark the row of causes of low efficiency of foreign language teaching at technical and non-language specialities. One of such causes can be identified as very few hours alloted to foreign languages teaching. But the main task of education is the practical possessing of the developed professionally oriented communicative competence for active application of a foreign language in professional communication.

At the present the main task of foreign language teaching is profession-oriented communication teaching, and the process of teaching itself must be practically oriented. That is, the universal methods of foreign language teaching should be searched for, that would allow to attain the higher level of specialists schooling due to the integration of language and professional spheres.

Foreign language teaching must take place within the limits of personality oriented, communication directed and professional activity approaches in the system of language profession-oriented training of students, on condition that the innovative foreign language education is oriented to the professional sphere and provides the clear criteria of the language competence evaluation, and should be implemented into the educational process.

\section{Theory}

Communicative competence is one of the kinds of competence, that is determined as integral personality resource that provides the success of communicative activity [1]. The necessity of foreign communicative competence forming is also marked in many regulatory documents on 
modernization strategies of universal education, materials of the Council of Europe "Key competencies for Europe" et al. Thus, in the materials on the key competences presented by the CE, the ability to communicate more than in one language was included into the list of five main competences recognized the most essential for all young Europeans; the special emphasis is also made on the study of a foreign language in connection with the necessity for all Europeans to master verbal and writing communication facilities both in a native and a foreign language that is a condition for professional and social success of a person [2] .

The questions of theory and practice of foreign communicative competence development of students have been illuminated in scientific works of many researchers, such as: N. Hez [8], I. Zymniaia [9], V. Safonova [1], A. Khutorskoi [7], J. Van Ek [14], et al. Although there have been a lot of publications on this issue, the authors stress that many of its aspects, and, first of all, the definition of the concept "foreign communicative competence" itself, its component composition, the peculiarities of its forming, the determination of its criteria and indicators formation remain to be not sufficiently studied [6].

The necessity to enhance the role of communicative disciplines in general is underlined in these works, and a foreign language is distinguished as a discipline that has the special value for realization of this task [3]. Thus, a foreign communicative competence, next to a communicative competence in a native language, is presently examined as one of the key competences on forming of which general education must be directed to. But, as some authors notice, in spite of the special importance of the foreign communicative competence and the fact that it is the most examined of all the key competences, theoretical and practical development of the competence approach in mastering a foreign language by a young specialist, a graduate student of a higher educational institution, as well as the determination of social professional specificity of this kind of competence, the criteria of its formation evaluating on this educational stage, however, remains the matter of the future [4].

\section{Results}

Within the framework of the competence approach the personality traits that allow a person to be successful in the society come to the foreground, and from this point of view, the advantages of active and group teaching methods are the following ones: priority attention to the development of collaborative skills, but not competitive ones, listening and communicative abilities, positive selfesteem, tolerance, understanding of other people, work and innovation encouragement.

The authors emphasize that communicative competence mastering at foreign language classes is a rather difficult problem, as students are not in the country of the studied language, and for this reason it is necessary to use the active methods of foreign languages teaching in modern institutions of higher education. The main purpose of the active methods of foreign languages teaching is the communicative competence forming, and all the other purposes (educational, developing, upbringing ones) will be fulfilled in the process of this primary objective realization. The fact that the communicative competence presupposes the formed capacities for cross-cultural communication appears to be very important as well. Profession-oriented, problem educational and speech situations, in some scientists` judgment, let the students make progress in the process of foreign professional communication mastering, that, in its turn, is the base of further foreign professional communication. The material of speech situations mastered in the process of discussion can be transferred to the environment of real communication with native speakers in the future [5].

\section{Discussion}

The limits inaccuracy of the term "foreign communicative competence" results in the great number of definitions, such as: speech competence, communicative literacy, verbal communicative competence, sociolinguistic competence, communicative capabilities, communicative abilities, communicative perfection and others. 
V. Safonova and A. Khutorskoi separate the concepts "competence" and "capacity". The concept "capacity" is determined as a capacity of a person for practical activity, and "competence" - as a content component of this ability in the form of knowledge, abilities and skills [1,7]. However, in scientific literature in most cases different authors use the terms "competence" and "capacity" as synonyms.

The researchers mark, that if to examine for convenience the personality features of students as certain "given" concepts, and to consider communicative experience acquisition as a certain prospect, hence the professional level of a specialist, i.e. his/her professional communicative competence will depend exactly on the presence or absence of the communicative competence [6].

Concerning the concept of communicative competence different researchers accentuate its different sides. For example, N.Hez determines the essence of communicative competence as a certain ability to use the language correctly in various socially determined situations [8]; I.Zymnia analyses this concept from the psychological point of view, as the ability of a subject to carry out the speech activity by speech behavior realization, that is adequate on the aim to different communicative tasks and situations [9]; M.Viatiutniev, who entered this term into home linguodidactics, understands the communicative competence as the choice and realization of speech behaviour programs depending on person's capabilities to orientate in a certain communicative situation [10].

According to the data of the researchers of A.Morozova and T.Kostiukova, the content analysis of foreign communicative concept realization, historical and their own pedagogical experience of professional foreign language training at non-language faculties of higher educational institutions, and the studying of different specialists' scientific positions on this issue (N.Hez, I.Zymniaia, Y.Passov, N.Khomsky and others), made it possible to describe the structure of this concept as a situational category that represents the capabilities of a future specialist as for the realization of knowledge (professional and linguistic ones), foreign communicative abilities (to carry out communication effectively), professional and personality features of a student (communicativeness, tolerance, capacities for psychological obstacles overcoming in the process of foreign communication) and foreign professional communication experience that facilitates the creative solving of practice oriented tasks arising in the process of studying [11].

As I.Mazaieva marks, that on the whole, as the analysis of foreign communicative competence concept various interpretations conducted by L.Heikhman shows, under this type of competence the ability and willingness to carry out foreign communication under certain requirements are presupposed, which are based on the certain complex of knowledge, abilities and skills specific for a foreign language, as, for example, proficiency in the language means and the processes of generation and recognition of speech, as well as grammatical, lexical and spelling knowledge, abilities and skills, pronouncing abilities and speech recognition, and also the ability to achieve the mutual understanding, or to solve a difficult situation in the language relation, and so on [12]. Hence, at present, the theoretical understanding of the foreign communicative competence is limited only to the range of knowledge, abilities and skills specific for a foreign language.

The foreign communicative competence has a difficult multicomponent structure, and there is no unanimity in understanding all its components and the mechanism of their cooperation. Let us stop for a while to consider this question in detail.

The communicative competence is determined as the main purpose of foreign language studying in the system of higher professional education, and is interpreted as the totality of a few subcompetences, namely: linguistic, sociolinguistic, discussion, strategic and sociocultural kinds of competence [9].

V. Safonova distinguishes the following components of foreign communicative competence: language (grammatical, linguistic) one; speech (pragmatic, strategic, discursive) one; sociocultural (sociolinguistic, culture-oriented linguistic) kinds of competence [1]. Such components, in opinion of the researchers, fully represent the content of foreign communicative competence and correspond to the aims of foreign language teaching in nonlanguage institutions of higher education.

The researchers distinguish the different aspects of this concept. For example, in accordance to the model, offered by the Council of Europe, the communicative competence consists of three basic 
components: linguistic (includes phonological, lexical and grammatical knowledge and abilities), sociolinguistic (it is determined by the sociocultural terms of the language use) and pragmatic (includes extralinguistic elements that provide communication, such as facial and body expression, et al) ones.

J. Sauvignon distinguishes four main components of foreign communicative competence: grammatical, sociolinguistic, compensatory and speech strategy kinds of competence. J. Van Ek discriminates six components of the above-mentioned concept: linguistic, sociocultural, sociolinguistic, strategic, discursive and social ones. Thus, sociocultural competence means the students` knowledge of national and cultural peculiarities of native speakers social and speech behaviour and the ability to use it in the process of communication. Discursive competence is the ability to generate a discourse, i.e. to use and interpret the forms of words and meanings for coherent texts composing. Strategic (or compensatory) competence supposes the use of verbal and nonverbal communicative strategies with the aim of compensation of lack of grammatical code knowledge $[6,14]$.

The majority of the researchers distinguish the following components (so-called "subcompetences"): 1) language (linguistic) subcompetence (interpreted as the ability of the speaker to generate the chain of grammatical phrases on the basis of the stated rules, even irrespective of their content); 2) sociolinguistic subcompetence (shows the ability to use and convert language forms in accordance with a situation, i.e. to carry out the choice of language forms depending on the description of a communicative situation: the place, the relations between communicators, the communicative intention, etc.); 3) sociocultural subcompetence (includes the knowledge of sociocultural context in which the language is used, and also the knowledge of the influence that a sociocultural context makes on the choice of language forms); 4) discursive subcompetence (the ability to understand and to attain the coherence of separate expressions in meaningful communicative models); 5) strategic subcompetence (the ability to use verbal and nonverbal strategies for the code knowledge defects indemnity by the user) $[12,4]$.

In general, as the researchers mark, the foreign communicative competence in its five components is distinguished by almost all the authors (language (linguistic), sociolinguistic, sociocultural, discursive and strategic ones), and can be correlated with the model of social professional competence of a specialist developed by I.Zymniaia. Thus, they consider that it is necessary to emphasize the fact that professional communicative abilities are not specified in the models of the general foreign competence, however, social competences have the effect on them. So, the correlation of foreign competence components with the blocks of the model finds out that so-called "subcompetences", like the social professional competences the author distinguishes, are realized by means of intellectual, mental actions (intellectual providing block), personality features of a person (block of personality features), as well as his/her social and professional abilities (block of social and professional competences). Thus, as the authors stress, the presenting of this kind of competence in the structure of the general model of social professional competence of a person opens the new viewpoint of its consideration in the structure of the only social professional competence of a specialist and allows to classify the component abilities of this competence in accordance with the blocks distinguished in the model of social professional competence [4].

A.Morozova, examining the question of foreign language teaching specifics at non-language faculties, distinguishes the most substantial contradictions: firstly, between the modern requirements to the level of practice-oriented knowledge formation, foreign communicative abilities, professional personality features of future specialists and insufficient schooling of specialists on the foreign language subject; secondly: between the researches of various aspects of students' professional competence and the actual lack of attention to the problem of foreign communicative competence development of students at non-language institutions of higher education; thirdly, between the necessity of increasing the level of practical knowledge of a foreign language by students of nonlanguage faculties with the aim of professional self-training and the lack of corresponding pedagogical conditions for competence development in the educational process of professional higher educational establishments [11]. 
In our opinion, quite an interesting approach to the problem of foreign communicative competence forming is offered by some modern researchers. They consider that it is necessary to work out the adequate, practice-oriented competence development levels, which represent its structure, namely: cognitive, operational and personality-oriented ones. Thus, mastering the set of professional and linguistic knowledge acquired by a student in the process of learning a foreign language for the purpose of communication in a foreign language is supposed by the cognitive level. In this case under professional knowledge the authors mean the aims, tasks and principles of professional activity, and under linguistic one they mean the knowledge of grammar, vocabulary and area studies. An operational level supposes the ability of a future specialist to realize pedagogical communication in a foreign language in the professional sphere, i.e. to support communication in a foreign language effectively in the process of practical application of the acquired knowledge of a subject.

The personality professional level appears in the presence of such professional personality features, as communicativeness, tolerance, capacities for psychological obstacles overcoming in the process of communication in a foreign language, and also the motivation of professional self-education when studying in the institution of higher education. And thus, the clarification of the professionoriented levels of this competence development opens the new possibilities of foreign communicative competence displays at the personality level in the process of studying in the institution of higher education [11].

The researchers mark that by means of the personality-oriented approach at foreign language classes the special conditions facilitating the development of students' creativity should be created, when a teacher acts as a consultant, performing as an observer. In case of any difficulties students cannot solve independently, the teacher can temporally play the role of a leader with the aim of granting certain psychological help to the students.

The creation and development of strong mutual relations among all the communicants (the teachers and the students) are considered to be the aim of communicative method application in the process of foreign communicative competence development of students. These relations should not offend the rights and dignity of interlocutors, as well as the displays of tolerance within the limits of crosscultural communication.

\section{Conclusions}

The topical issue of present time higher education, exactly the preparation of highly qualified experts, competent in the professional fields of activity must be settled in the process of professional communicative competence development by means of foreign language teaching.

In the process of professional communicative competence development of higher educational establishments graduates by means of teaching such a discipline as a foreign language, the urgent problem of present time higher education might be solved, namely the preparation of highly skilled, all-round developed specialists competent in their professional sphere of activity.

\section{References}

[1] V.V. Safonova, Social and cultural approaches to foreign languages teaching as a speciality, (1993). (in Russian)

[2] Symposium on Key Competencies in Europe. Report of the Symposium, Strasbourg, Council for Cultural Cooperation, 1997.

[3] The strategy of general education content enhancement, Materials on general education papers development (2001). (in Russian)

[4] I.A. Mazaieva, Foreign communicative competence as a component of social and professional competence of university graduates, Research centre of specialists training problems, 2006. (in Russian) 
[5] O.V. Sumtsova, The formation of foreign communicative competence of technical institutes students with the help of active methods of foreign languages teaching, Young scientist. 2 (2012) 297-298. (in Russian)

[6] M.A. Bushuieva, The formation of foreign communicative competence of non-philological specialities students, Perm State Pedagogical University Press. (2009) 117-121. (in Russian)

[7] A.V. Khutorskoi, The key competences and educational standarts, Eidos. (2002). http://www.eidos.ru/journal/2002/0423.htm (in Russian)

[8] N.I. Hez, The formation of communicative competence as the object of foreign methodological research, Foreign languages in schools. 2 (1985) 17-24. (in Russian)

[9] I.A. Zimniaia, Psychology of foreign languages teaching in schools, Education, Moscow, 1991. (in Russian)

[10] M.N. Vyatyutnev, The communicative focus of teaching of the Russian language in the foreign schools, Russian language abroad. 6 (1977) 38-45. (in Russian)

[11] A.L. Morozova, Development of foreign communicative competence of non-philological specialities students, Tomsk Politechnic University Press, 2011. (in Russian)

[12] L.K. Heikhman, Interactive communication teaching (general pedagogical approach), Ekaterinburg, 2003. (in Russian)

[13] N.S. Sakharova, Development of foreign communicative competence of university students, Creative centre, 2003. (in Russian)

[14] J.A. Van Ek, J.L.M. Trim, Threshold 1990, Strasbourg, Council of Europe Press, 1991. 